\title{
ハイブリッドポロイダル磁界コイルによる トカマクプラズマの電流・平衡制御
}

正員嶋田隆一 (原研)

\section{1. まえがき}

トカマク形核融合装置は環状真空容器内の磁界( ロイダル磁界）中にトーラス状のプラズマを発生させ トロイダル方向にプラズマ電流を流すととを特徴とし ている。トカマク装置に执いては，トロイダル磁界の 発生と共に，プラズマ中にトロイダル方向汇電流を流 すととと，プラズマの平衡を取るととは，装置にとっ て最も基本的な機能であり，このなかでプラズマ電流 と平衡制御はポロイダル磁界コイルによってなされて いる。この二つの機能，プラズマ電流の駆動と平衡制 御は, 従来ポロイダル磁界コイル系化要求される独立 した機能と考えられてきた。それは，従来のトカマク が一般に変流器作用のための鉄心を有し，プラズマ電 流の駆動が鉄心を介した变流器コイル電源によってな されており，平衡必要な垂直磁界は更に別なコイル により別電源から発生させる形であったためである。 そこには，第一にプラズマ電流の励起があり，第二に そのプラズマを平衡位置に置くため, 垂直磁界コイル に電流を流すといった考え方が主であった。よって, プラズマの平衡制御とプラズマ電流の制御とは独立に 考えて設計され，しかして運転，制御されるのが一般 的であった。

最近の大形化されたトカマク装置は，従来使用され てきた鉄心がプラズマ電流駆動のための磁束変化量に 対し, 制限を与えるため使用が困難となり, 空心構造 のトカマクが多くなっている(1)。例えば，原子力研究 所に战いて建設中の JT-60 の場合は，プラズマの周 团にポロイダル磁界コイルを多数置き，そのなかで変 流器コイルと呼ばれるコイル群はプラズマ電流を流す ことのみに使用され，垂直磁界コイルと乎ばれるコイ 儿群は垂直磁界を発生して平衡を取るために使用され

Controls of Tokamak Plasma Current and Equilibrium with Hybrid Poloidal Field Coils. By Ryuichi Shimada, Member (Division of Large Tokamak Development, Japan Atomic Energy Research Institute.).

实田隆一：正貝，日本原子力研筑所大型トカマク開発部
る(2)。すなわち，鉄心のあるトカマクの場合の運転形 龍をそっくり空心の場合に移した形となっている。ポ ロイダル磁界コイルは，それぞれ直列接続されたコイ 儿群に分加れ，それぞれが变流器磁界，垂直磁界，四 重極磁界などの単一のパターンを発生するコイル群と なっている(る)(4)。

てれに対し，プラズマの周囲に置かれた各コイルに それぞれ必要な大きさの電流を流し，変流器コイル・ 垂直磁界コイルと分けるととなしに単にポロイダル磁 界コイルとして，必要な磁界パターンを発生すること が考えられる。プラズマの周辺で同し磁界環境である ならば，これも前者と同じようにプラズマ電流の駆動 とプラズマの平衡をとることができる。このような場 合, 一本のコイルに変流器磁界成分, 垂直磁界成分な どの電流が一緒に流れることが特徴であるので，八イ ブリッド磁界コイルと呼ぶととにする。

ハイブリッド磁界コイル法はトカマクが核融合弱之 して大形化される際に必要な条件を多くすっている。 本諭文では，核融合师を目指したトカマク形核融合装 置におけるプラズマの電流・平衡制御に対して，ポロ イダル磁界系の制御法について考察する。すなわち， ハイブリッド制御マトリックスなるもの綨入し，各 コイルに流すべき電流が容易に算出できる方法を示 す。また，てのようなハイブリッドポロイダル磁界コ イル系の駆動電源倿対し，各コイル巻数を適切汇選定 することにより，プラズマ電流の励起時にプラズマの 駆動とプラズマの平衡制御が基本的には単一電源で可 能なととも示す。これらの考え方はトカマク形核融合 弱のポロイダル磁界電源の設備容量を滅少させると共 に，システムの基本的構成を決定するむのである。最 後に，以上の考元方加ら構成されるハイブリッド戈口 イダル磁界コイル電源の具体的な構成について示す。

\section{2. 軸対称プラズマの平衡}

トカマクプラズマの磁界設計において，従来プラズ マ電流に代表されるプラズマパラメータを固定して， 
プラズマ電流のフープ力, プラズマの生力に対して垂 直磁界を印加して，これらの力とつり合いを取るとと が平衡条件の基本で古ると言う考え方が主であっ た(5)。乙こでは，ハイブリッドポロイダル磁界コイル の特徴であるプラズマ電流歌動とプラズマ平衡制御を 同時に行なうために必要な，プラズマ電流老固定しな いトカマクプラズマの平衡条件を求める。まず，トカ マクプラズマを閉じ込めているのは，プラズマ電流亡 ポロイダル磁界コイル電流の作る合成磁界であるとの 考え方にもとらねばならない。

プラズマの平衡条件は良く知られた次式より導かれ る。

$$
\begin{aligned}
& \left.\begin{array}{l}
\nabla P=\boldsymbol{j} \times \boldsymbol{B} \\
\nabla \times \boldsymbol{B}=\mu_{0} \boldsymbol{j} \\
\operatorname{div} \boldsymbol{B}=0
\end{array}\right\} \ldots \ldots \ldots \ldots \ldots \ldots \ldots \ldots \ldots \ldots \ldots \ldots \ldots \ldots \ldots \\
& \text { ここで, } P: \text { プラズマの生力, } \boldsymbol{j}: \text { ブラズ マ }
\end{aligned}
$$

電流の密度, $\boldsymbol{B}$ : 磁束密度

トロイダル方向に軲対称なシステムにおいて $(r, \varphi, z)$ の円筒座標老用いれば，ベクトルポテンシャル $\boldsymbol{A}$ は $\partial / \partial \varphi=0$ より $\varphi$ 成分のみとなり， $\Psi=r A_{\varphi}$ と書くこ

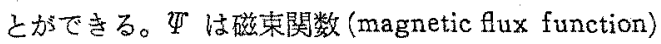
と呼代れる(6)。(r，z) 面での $\Psi$ がわかると磁力線の 形がわかり，更に $\varphi$ 方向に $\Psi=$ 一定の面は磁気面を 表わしている。すなわち，

$$
\boldsymbol{B} \cdot \nabla \Psi=0
$$

である。プラズマの平衡条件 (1)式より

$$
\boldsymbol{B} \cdot \nabla P=\boldsymbol{B} \cdot \boldsymbol{j} \times \boldsymbol{B}=0 \text {. }
$$

と畫りることにより，(2)式と(3)式のアナロジーよ b $P=$ 一定は $\Psi=$ 一定に対応し，一つの磁気面を形 つ゚くることがわかる。これがプラズマの平衡条件であ る。とこで，プラズマの最外郭（すなわち，プラズマ 表面）を考光る。その面より外部はプラズマ電流がな い。最外部面のプラズマ圧力は $P=P_{S}$ で一定である (真空であれば $P_{s}=0$ )。その面上では $\Psi=$ 一定であ り，磁気面である。プラズマ最外部磁気面の形状は， すなわちプラズマの外形であり，逆にとの目標となる 形の面上で $\Psi=$ 一定とすることができればプラズマ の平衡は突現できる。

プラズマの表面上の磁束関数值 $\Psi_{B}$ はブラズマ篦流 の寄与とプラズマ外のコイル電流の寄与の合成値であ ることに迬目しなければならない。一般にプラズマの 平衡問題を取扱う場合，プラズマ内と外を分りて解き 境界条件で結び合せるのが普通である(7)(8)。またプ ラズマ内外の闍題を同時に解くこともできる(9)。とこ では，前者の立場に立ってプラズマ内部の平衡問題は
既に解かれているとする。このときプラズマ最外新磁 気面の磁束関数值は任意の值を取ることがでさる。

このようにプラズマ内の電流分布をプラズマ平衡で 求め，その境界条件を与えたプラズマ最外郭磁気面上 での磁束関数值が，ブラズマ電流とコイル電流による 磁束関数值の合成で一定值とすることができれい゙輀者 の境界条件が一致したことになり，プラズマの平衡は 内多多すべて解けたことになる。

\section{3. プラズマ外部の平衡磁界}

Zakharov 氏(10)(11) はプラズマ外の仮想面上儿分布 するプラズマ保持用の電流を楀分方程式で求める方法 を示したが，ここではプラズマ外にブロック化されて 置かれたポロイダル磁框コイルに流すべき電流をマト リックス計算で求める方法を示す。

〈3.1〉 プラズマ電流がブラズマ表面に作る $\boldsymbol{\Psi}$ (図 1 参照) プラズマ内の電流分布は $j\left(r_{P}, z_{P}\right)$ で与え られているとする。この電流がプラズマの表面上の参 照点 $\left(r_{B}, z_{B}\right)$ に作る磁束関数值 $\Psi_{B P}$ は完全だ円皘分 で表わされる関数 $G\left(r_{P}, z_{P}, r_{B}, z_{B}\right)$ によって求めら れる。

$$
\Psi_{B}=r_{B} A_{\varphi}=G\left(r_{P}, z_{P}, r_{B}, z_{B}\right) j\left(r_{P}, z_{P}\right)
$$

関数 $G$ は冈電流の作るべクトルポテンシャルより

$$
\begin{aligned}
& G\left(r_{P}, z_{P}, r_{B}, z_{B}\right) \\
& \quad=\frac{\mu_{0}}{\pi} \frac{V r_{P} r_{B}}{k}\left\{\left(1-\frac{k^{2}}{2}\right) K(k)-E(k)\right\}
\end{aligned}
$$

$$
\begin{aligned}
& \text { ここで, } \\
& \qquad k^{2}=4 r_{P} r_{B} /\left\{\left(r_{P}+r_{B}\right)^{2}+\left(z_{P}-z_{B}\right)^{2}\right\}
\end{aligned}
$$$$
K, E: \text { 第一，二䘄完全だ円積分 }{ }^{(12)}
$$

よって，全プラズマ電流によって作られる参照点 $\left(z_{B}, z_{B}\right)$ における磁束閔数值 $\Psi_{B P}$ は

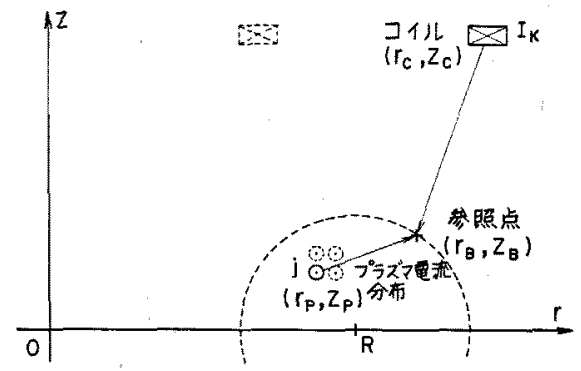

脑 1 プラズマ内外の電流がプラズマ表面に 作亏磁束関数值

Fig. 1. Flux function at the plasma surface produced by the currents inner and outer plasma. 
$\Psi_{B P}=\sum_{P} G\left(r_{P}, z_{P}, r_{B}, z_{B}\right) j\left(r_{P}, z_{P}\right)$

プラズマ全電流は $\sum_{P} j\left(r_{P}, z_{P}\right)$ である。

ここで，プラズマ電流の分布をプラズマ中心による 同軸状とすると，プラズマ中心に全電流が集中してい るとして取扱っても，トロイダル效果の誤差を無視し た形であるが，次のように簡単になる。

全プラズマ電流 $I_{P}$ の作るプラズマ表面の $\Psi_{B P}$ は プラズマの中心を $R$ として $\Psi_{B P}=G\left(R, 0, r_{B}, z_{B}\right) I_{P}$ となる。

〈3.2〉 ポロイダル磁界コイル電流がプラズマ表面 に作る $\Psi$ (図 1 参照) 1 個のコイル $\left(r_{c}, z_{c}\right)$ に流 れる電流を $I_{K}$ とすると，プラズマ表面上の参照点 $\left(r_{B}, z_{B}\right)$ 亿作る磁束関数値は $G\left(r_{c}, z c, r_{B}, z_{B}\right) I_{K}$ で 京る。

プラズマの周りに n本のコイルがあり，それぞれ $I_{K}(K=1, \cdots, n)$ の電流が流れているとすれば; プラ ズマ表面上の点 $\left(r_{B}, z_{B}\right)$ の磁束関数は

$$
\Psi_{B C}=\sum_{K=1}^{n} G\left(r_{C K}, z_{C K}, r_{B}, z_{B}\right) I_{K}
$$

で求められる。

〈3.3〉 プラズマ表面の $\Psi$ 以上より，すべての 電流がプラズマ表面の点 $\left(r_{B}, z_{B}\right)$ に作る磁束関数值 $\Psi_{B}$ は， $\Psi_{B C}$ と $\Psi_{B P}$ の和であるから次式となる。

$$
\begin{aligned}
\Psi_{B}= & \sum_{P} G\left(r_{P}, z_{P}, r_{B}, z_{B}\right) j\left(r_{P}, z_{P}\right) \\
& +\sum_{K=1}^{n} G\left(r_{C K}, z_{C K}, r_{B}, z_{B}\right) I_{K}
\end{aligned}
$$

プラズマが同軸状電流分布のときは，簡単になって

$\Psi_{B}=G\left(R, 0, r_{B}, z_{B}\right) I_{P}$

$$
+\sum_{K=1}^{n} G\left(r_{C K}, z_{C K}, r_{B}, z_{B}\right) I_{K}
$$

である。プラズマ表面に多数（ $m$ 個）の参照点 $\left(r_{B}\right.$, $z_{B}$ ）をとり，それらの点䖞すへて等しい $\Psi_{B}$ となるこ とがプラズマ表面が磁気面となる条件であるから， (9)式はマトリックスで表わせば以下のようになる。

$$
\begin{gathered}
m\left\{\begin{array}{c}
1 \\
1 \\
\vdots \\
1
\end{array}\right) \Psi_{B}=\left(\begin{array}{c}
G\left(R, 0, r_{B 1}, z_{B 1}\right) \\
\vdots \\
\vdots \\
G\left(R, 0, r_{B m}, z_{B m}\right)
\end{array}\right) I_{P} \\
\left.+\left(\begin{array}{c}
G\left(r_{C 1}, z_{C 1}, r_{B 1}, z_{B 1}\right), \cdots \\
\vdots \\
\vdots \\
* \quad \\
\cdots G\left(r_{C n}, z_{C n}, r_{B m}, z_{B m}\right)
\end{array}\right)\left(\begin{array}{c}
I_{1} \\
I_{2} \\
\vdots \\
I_{n}
\end{array}\right)\right\}
\end{gathered}
$$

右边第 1 項の $m$ 行, 1 列の係数列, 第 2 項の $m$ 行, $n$ 列のマトリックスをそれぞれ $\left[F_{P}\right],[F]$ とする。プ ラズマ電流の分布を考える場合は第1 項もマトリック スとすればよい。プラズマ表面上に取った任意の $m$ 点 がすべて $\Psi_{B}=$ 一定となることが最外郭磁気面となる 条件であり，境界条件が満たされることになる。プラ ズマ外部の平衡条件とは(10)式を満たすことである。

\section{4. ハイブリッド制御マトリックスを用いた コイル電流の決定法}

プラズマの平衡条件が(10)式で与えられるとき，プ ラズマ電流に対して各コイルに流すべき電流は次のよ うに求められる。

(10)式よりコイル電流を求めるには，プラズマ表面 の参照点 $\left(r_{B}, z_{B}\right)$ 加コイル本数 $(n)$ 以上ある必要驾 ある $(m \geq n) 。 m$ を多くして，最少 2 乗法で (10)式を 解けば必要な精度でコイル電流值が与えられる。しか し，参照点を適切な位置に $n$ 点選べば原理的に同粎な ので，式を扱いやすくするために $m=n$ として進め る。(10) 式を $m=n$ としてコイル電流を求めると次の ようになる。

$$
\left(\begin{array}{c}
I_{1} \\
I_{2} \\
\vdots \\
\dot{I}_{n}
\end{array}\right)=(F)^{-1}\left(\left(\begin{array}{c}
1 \\
1 \\
\vdots \\
1
\end{array}\right) \Psi_{B}-\left(F_{P}\right) I_{P}\right)
$$

このように，プラズマ電流とプラズマ最外郭磁気面 の磁束関数值 $\Psi_{B}$ を与えれば，各コイルに流すべき電 流值 (I) が求められる。(11)式において右辺の第 1 項 は $I_{P}=0$ のとき最外郭磁気面で磁束関数を一定とす るコイル電流値を与えていることになる。 $I_{P}=0$ では プラズマ中に磁束がないととより，乙の電流はいわゆ る变流器コイルの磁界パターン(プラズマ領域に磁力 線がない，すなわち磁束関数值が一定である領域）を 作る。第 2 項はプラズマ電流が存在すると必要になる コイル電流を与える項で，との電流はプラズマの保持 用の磁界を作る。各コイルには変流器コイル成分と平 衡磁界成分の和の電流を流すととになり，変流器と平 衡コイルとのハイブリッドコイルとなっている。変流 器コイル成分から平衡磁界成分を引いた形になってい るので，それぞれ独立に流すコイル系を持った場合よ り総電流（アンペアターン）が小さくなる可能性があ る。てれを利用すれば合理的なコイルシステムが可能 であり、コイル駆動電源の設備容量も減少できる。

(11)式の $\Psi_{B}, I_{P}$ を注目して以下のように書き換え $\tau$ 


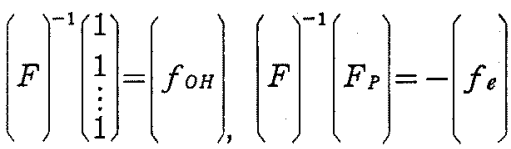

とすると

$$
\left(\begin{array}{c}
I_{1} \\
I_{2} \\
\vdots \\
I_{n}
\end{array}\right)=\left(f_{O H}\right) \Psi_{B}+\left(f_{e}\right) I_{P}
$$

$f_{\circ H}$ は変流器コイル成分の各コイルの電流值を与 える係数である。f，む同㥞にプラズマの平衡に必要 な各コイル電流值を与える。(12)式の係数列を次のよ うに書き換えて，コイル電流のハイブリッド制御々卜 リックスなるすのを定義する。

$$
\left.\left(\begin{array}{c}
I_{1} \\
I_{2} \\
\vdots \\
I_{n}
\end{array}\right)=H\right)\left[\begin{array}{c}
\Psi_{B} \\
I_{P}
\end{array}\right]
$$

これは，ハイブリッドポロイダル磁界コイルの運転 制御を行なう際，非常汇有益なマトリックスとなる。

ここで，プラズマ表面の磁束関数值 $\Psi_{B}$ について考 察する。仮にプラズマ表面にトロイダル方向に 1 周巻 楾を置いたとすると，その1周巻線に誘起する電圧は 鎖交フラックスの時間変化 $=-R_{P} I_{P}-L_{i} I_{P}$ である。

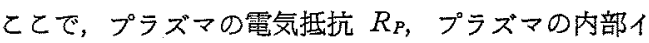
ンダクタンスを $L_{i}$ とする。鎖交フラックス量は磁束 関数值を $\varphi$ 方向に 1 周積分して得られ，上って值は $2 \pi$ 倍である。

$$
\begin{aligned}
& \dot{\Psi}_{B}=\left(-R_{P}-L_{i} I_{P}\right) / 2 \pi \ldots \ldots \ldots \ldots \ldots \\
& \Psi_{B}=\Psi_{B}(0)-\left(\int_{0}^{t} R_{P} I_{P} d t+L_{i} I_{P}\right) / 2 \pi
\end{aligned}
$$

となる。 $\Psi_{B}(0)$ は $t=0$ 時の值である。

このように, $\Psi_{B}$ は $\Psi_{B}(0), \int_{0}^{t} R_{P} I_{P} d t, L_{i} I_{P}$ と三 つの要素の和であるとするととができる。(13)式の IPに対して木プラズマの平衡制御に関連する変数と して, $\beta_{P}$ (プラズマのポロイダルベータ)， $\Delta R$ (大半 径方向の変位), $\Delta H$ (上下方向の変位), $\Delta \delta$ (断面形状 の変化）などを必要に応じて採用し，ハイブリッド制 御マトリックス $\boldsymbol{H}$ の列を增加させることにより平衡 记関するいかなる制御むコイル電流に反映することが できる。

\section{5. ハイブリッドポロイダル磁界コイルによ} るトカマクプラズマ電流・平衡制御の例

ここでは，第3章，第 4 章で導いたコイル電流の決 定法を次の諸元のトカマク装置に適用し，ハイブリッ
ド制御マトリックスの応用例を示すととにする。また 磁束関数值の空間分布を求め，このコイル電流でプラ ズマの平衡が取れていることを示す。

プラズマ大半径 (小半径)：5m (1.5m)

断面形状 : 円形

最大プラズマ電流： $4.7 \mathrm{MA}$

プラズマ電流分布：2 乗分布

プラズマ電流立上げ時間 : $5 \mathrm{~s}$

プラズマ電流フラット，トップ時間 : $200 \mathrm{~s}$

プラズマ電流立下げ時閪： $5 \mathrm{~s}$

ポロイダル磁界コイル本数: 10 本

コイル位置 (上下対称)：プラズマ中心より $3.7 \mathrm{~m} の$ 所比 $36^{\circ}$ 間隔

コイル名 $=(R, Z) \quad C_{1}=(8.52,1.14)$

$$
\begin{aligned}
& C_{2}=(7.18,2.99), C_{3}=(5.0,3.7) \\
& C_{4}=(2.83,2.99), C_{5}=(1.48,1.14)
\end{aligned}
$$

$\Psi_{B}(0) *(\mathrm{~V} \cdot \mathrm{s}$ 換算) $: 5.132(32.25 \mathrm{~V} \cdot \mathrm{s})$

〈5・1〉ハイブリッド制御マトリックスの值プラ ズマ表面上に参照点を 10 個選ぶ。これは $R=5 \mathrm{~m}$, $Z=0$ を中心とする半径 $1.5 \mathrm{~m}$ の円上に等間隔に取る。 (10)〜(13)式の上うに整理してハイブリッド制御マト リックスができる。(16)式に示す。

$$
\left(\begin{array}{c}
I_{1} \\
I_{2} \\
\vdots \\
\vdots \\
\vdots \\
\vdots \\
\vdots \\
\vdots \\
I_{10}
\end{array}\right)=\left(\begin{array}{ll}
0.0237 & -0.1271 \\
0.0415 & -0.1493 \\
0.1181 & -0.2171 \\
0.4431 & -0.4244 \\
1.8123 & -1.0432 \\
0.0236 & -0.1271 \\
0.0415 & -0.1494 \\
0.1181 & -0.2170 \\
0.4432 & -0.4247 \\
1.8122 & -1.0428
\end{array}\right)^{10^{\circ}}\left[\begin{array}{c}
\Psi_{B} \\
I_{P}
\end{array}\right] \ldots
$$

ただし，IP：MA 単位

〈5.2〉ハイブリッド制御マトリックスを用いたコ イル電流の決定（16)式に示した $\boldsymbol{H}$ マトリックス が求まると各コイル電流值がわかる。 $\Psi_{B}, L_{i}$ は

$$
\begin{aligned}
\Psi_{B} & =\Psi_{B}(0)-\int_{0}^{t} R_{P} I_{P} d t / 2 \pi-L_{i} I_{P} / 2 \pi \\
L_{i} & =\mu_{0} R l_{i} / 2\left(l_{i}=1.0, \quad 2 \text { 乗分布 }\right) \\
& =3.14 \mu \mathrm{H}
\end{aligned}
$$

である。

プラズマ電流の波形，その間の $\int R_{P} I_{P} d t$ の間を表 1のように仮定すると，1サイクルのコイル電流の運 軽波形が求められる。コイル電流は (16)式に $\Psi_{B}, I_{P}$

*: $\Psi_{B}(0)$ の值は任意であるが，こてではコイルの総ナンペアター ンの絶刘植肪最初之最後で等しくなるように選んだ。 
表 1 プラズマ電流值と $\int R_{P} I_{P} d t$ の值

Table 1. Plasma current and $\int R_{P} I_{P} d t$.

\begin{tabular}{l|c|c|c|c|c}
\hline \multicolumn{1}{c|}{$(\mathrm{s})$} & $\Psi_{B}(0)$ & $I_{P}$ & $\int_{\mathrm{M}}{ }^{t} R_{P} I_{P} d t$ & $L_{i} I_{P}$ & $\Psi_{B}$ \\
\hline$t=0$ & 5.132 & 0 & 0 & 0 & 5.132 \\
$t=1.0$ & $\prime \prime$ & 1.0 & 3.0 & 3.14 & 4.155 \\
$t=2.35$ & $" \prime$ & 2.2 & 4.0 & 6.91 & 3.4 \\
$t=3.5$ & $"$ & 3.3 & 5.0 & 10.36 & 2.69 \\
$t=5.0 * 1$ & $"$ & 4.7 & 6.0 & 14.75 & 1.83 \\
$t=205.0^{* 2}$ & $"$ & 4.7 & $20+6$ & 14.75 & -1.353 \\
$t=210.0$ & $"$ & 0 & $26+6$ & 0 & 0.039 \\
\hline
\end{tabular}

*1: フラット・トップ型始、*2: フラット・トップ終了

$\Psi_{B}=\Psi_{B_{(0)}}-\int R_{P} I_{P} d t / 2 \pi-L_{i} I_{P} / 2 \pi$

表 2 コイル電流值

Table 2. Values of coil currents.

\begin{tabular}{l|c|c|c|c|c}
\hline \multicolumn{1}{c|}{$(\mathrm{s})$} & $C_{1}$ & $C_{2}$ & $C_{3}$ & $C_{4}$ & $C_{5}$ \\
\hline$t=0$ & 0.12 & 0.21 & 0.61 & 2.27 & 9.30 \\
$t=1.0$ & -0.028 & 0.023 & 0.27 & 1.43 & 6.49 \\
$t=2.35$ & -0.20 & -0.17 & -0.076 & 0.57 & 3.87 \\
$t=3.5$ & -0.36 & -0.38 & -0.40 & -0.21 & 1.43 \\
$t=5.0$ & -0.55 & -0.63 & -0.80 & -1.18 & -1.59 \\
$t=205.0$ & -0.63 & -0.76 & -1.18 & -2.59 & -7.36 \\
$t=210.0$ & 0.00092 & 0.0016 & 0.0046 & 0.017 & 0.071 \\
\hline
\end{tabular}

を代入して計算する。コイル電流は上下対称であるの で，C啨の電流を表 2 に示す。

このように1サイクルの運転波形が $\boldsymbol{H}$ マトリック スを用いることで容易に求められる。コイル電流の時 䦧波形を図 2 亿示す。

〈5.3〉磁束関数值の分布 表 2 亿示すようにコ イル電流が求められたが，乙れがプラズマの平衡条件 を満たすかどうかを磁束関数值の分布を見ることで調 ベる。

磁束関数值进プラズマ内, ポロイダルコイルの周辺 の全 $(R, Z)$ 平面で求め, 鳥㒈図として磁束関数の値

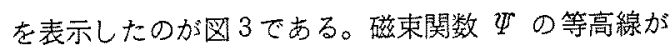

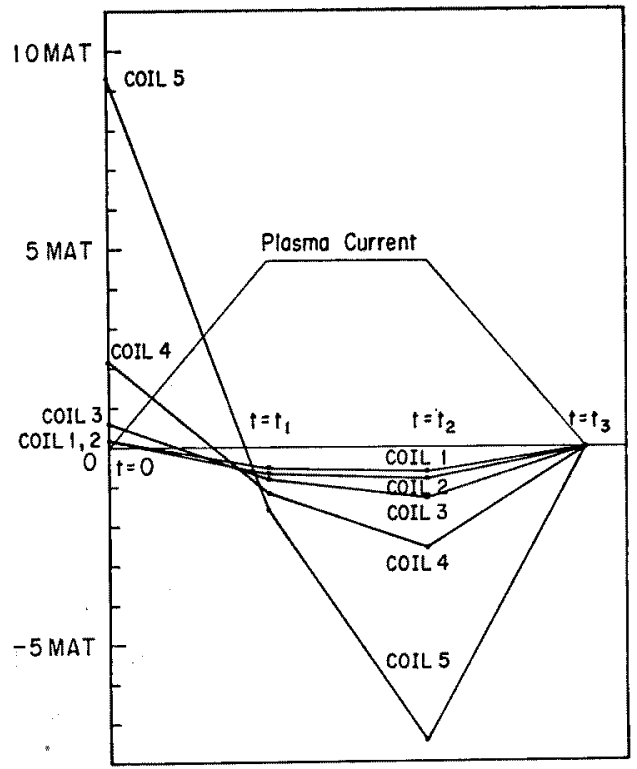

図 2 コイル電流波形

Fig. 2. Waveforms of coil currents.

磁力線に相当する。（a）図は $t=0$ の 值を示したす のである。プラズマ表面で $\Psi_{B}=\Psi_{B}(0)$ となるコイル 電流で作られた $\Psi$ 分布である。プラズマ領域でフラ ットな $\Psi$ 分布となっている。（b)〜（e）园は $t=1 \sim$ 5s と時間が経過した場合で，コイル電流はそれぞれ プラズマ表面での $\Psi$ を $\Psi_{B}$ とするために変化した様 子がわかる。 $\Psi_{B}$ 依表1の值になっており，プラズマ はその位置で平衡が取れている。(e)四は $t=5 \mathrm{~s}$, フ ラット・トップに達した時間である。コイル電流は真 へ上逆転し，その反作用としてプラズマ電流加 4.7 MA に励起されている。（f）図は $t=205 \mathrm{~s}, 200 \mathrm{~s} の$ フラット・トップの俊の $\Psi$ 分布である。とのとき:プ ラズマ表面での $\Psi$ 值は -1.353 て定となっており， プラズマの平衡は満たされている。

表 3 単能コイル方式，ハイブリッド方式電源容量の概算

Table 3. Estimations of power supply capacity of non-hybrid and hybrid coil system.

\begin{tabular}{|c|c|c|c|c|c|c|c|c|c|c|}
\hline & 管 源 種 別 & 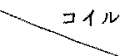 & $C_{1}$ & $C_{2}$ & $C_{3}$ & $C_{4}$ & $C_{5}$ & 算位 & \multicolumn{2}{|c|}{ 電源総容量 } \\
\hline \multirow{4}{*}{ 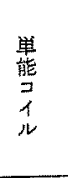 } & \multirow{2}{*}{ 変流器電源 } & 電流容量 & 0.12 & 0.21 & 0.61 & 2.27 & 9.3 & MAT & \multirow{2}{*}{$312.7 \times 2$} & \multirow{4}{*}{$1,086 \mathrm{MW}$} \\
\hline & & 発生䉓代 & $25 *$ & $\longleftarrow$ & $\longleftarrow$ & $\longleftarrow$ & $\longleftarrow$ & $\mathrm{V} / \mathrm{T}$ & & \\
\hline & \multirow{2}{*}{ 保持磁界用衊源 } & 電流容蜸 & 0.6 & 0.7 & 1.02 & 2.0 & 4.9 & MAT & \multirow{2}{*}{$230 \times 2$} & \\
\hline & & 発生䉓珃 & $25 *$ & $\longleftarrow$ & $\leftarrow$ & $\longleftarrow$ & $\longleftarrow$ & $\mathrm{V} / \mathrm{T}$ & & \\
\hline \multirow{2}{*}{ 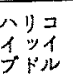 } & \multirow{2}{*}{ ハイブリッド制鹳要源 } & 笔流容篟 & 0.63 & 0.76 & 1.18 & 2.59 & 9.3 & MAT & \multirow{2}{*}{\multicolumn{2}{|c|}{$361.5 \times 2=723 \mathrm{MW}$}} \\
\hline & & 発生籍圧 & $25^{*}$ & $\longleftarrow$ & $\longleftarrow$ & $\longleftarrow$ & $\longleftarrow$ & $V / T$ & & \\
\hline
\end{tabular}

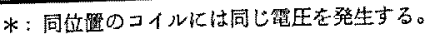



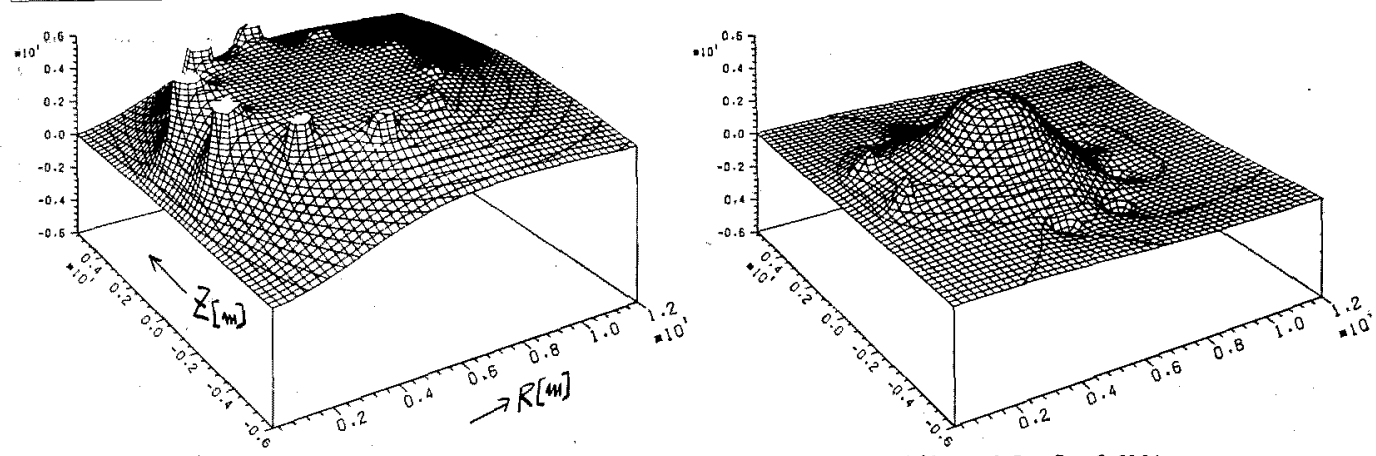

(a) $t=0, \quad I_{p}=0$

(d) $t=3.5 s, I_{P}=3.3 \mathrm{MA}$
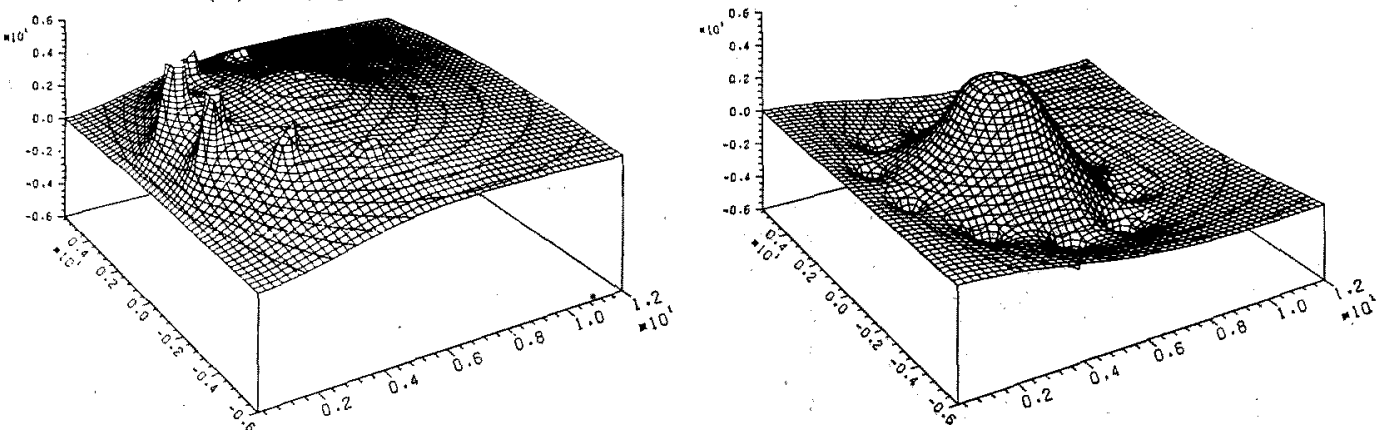

(b) $t=1.0 \mathrm{~s}, I_{P}=1.0 \mathrm{MA}$

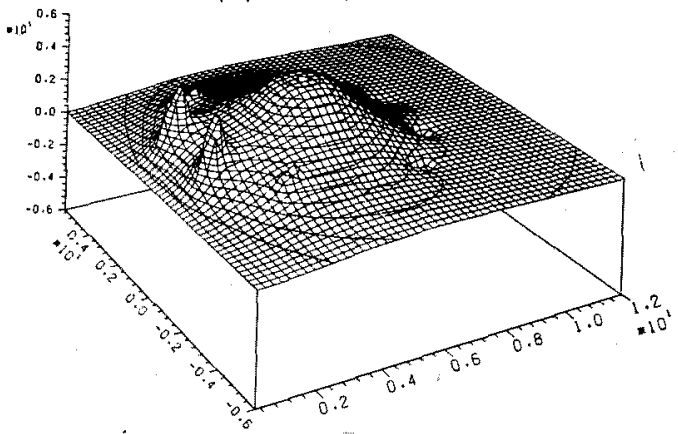

(e) $t=5 \mathrm{~s}, \quad I_{p}=4.7 \mathrm{MA}$

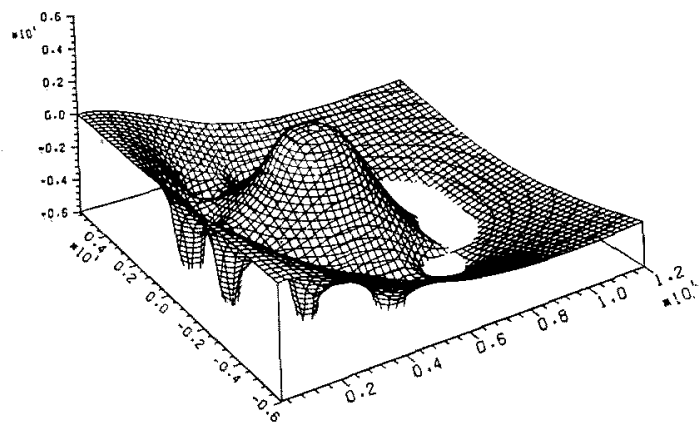

(f) $t=205 \mathrm{~s}, I_{P}=4.7 \mathrm{MA}$

図 3 磁束関数値の $(r, z)$ 空間分布

Fig. 3. $(r, z)$ space distribution of flux function.

〈5.4〉 電源設備容量の比較 ハイブリッド方式 を用いない場合, プラズマ電流駆動のための変流器コ イルとプラズマの平衡保持のための保持磁界コイルが 必要である(単能コイル方式)。全く同じ運転シナリオ で装置を動加す場合の電源設備容量を比較する。変流 器電源, 保持磁界電源の発生すべき電流は, (16)式の $\Psi_{B}, I_{P}$ に対応する電流である。なお，電源の出力電 圧はプラズマ電流の胁起初期に必要な一周電圧を考慮 して $25 \mathrm{~V}$ と仮定する。

表 3 に単能コイル力式の変流器コイル電源, 保持磁 界電源の容量, および八イブリッドコイル方式の電源 容量を示す。ハイブリッドコイル方式をとれば，設備 容量は $2 / 3$ になるととがわかる。

\section{6. ハイブリッドコイルの制御法}

トカマクプラズマを目標とする形状に保持しながら プラズマ電流を立上げ，維持するには，各コイルに (13)式化よって示される電流を流すへく電源電生を制 御すればよい。

まず，プラズマの平衡を維持しつつプラズマ電流を 制御するには，ポロイダル磁界コイル（プラズマの周 囲に配置されたポロイダルフープ）にどのような電圧 を印加すべきかを解析的に扱える単純な場合について 考察し，その後一般の場合に抬張する。

$\langle 6 \cdot 1\rangle$ コイル抵抗が零, 電流分布が均一表面電流. 分布のワンターンのポロイダルフープをポロイダル磁. 


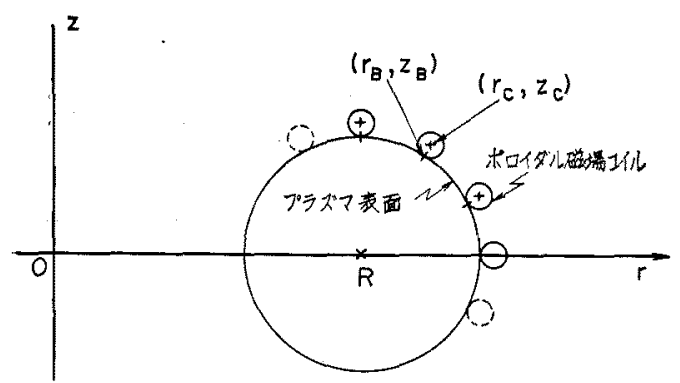

困 4 ポロイダル磁界コイルか理想的位置にある場合 Fig. 4. Case of the ideal locations of the poloidal field coil.

界コイルとし，コイル表面がプラズマ表面に接してい る場合のコイルの制御法 プラズマの表面とコイル の間には賁空容器がなければならないが, 解析の例と して図 4 のようにコイル表面までプラズマがある場合 を考える。第2章で述べたように，プラズマ表面はプ ラズマの最外郭磁気面となり，磁束関数 $\Psi_{B}$ が一定で あればよいのだから，各コイルに流すべき電流は(11) 式より決まる。このときプラズマ表面の参照点は、コ イルとプラズマ表面の接点にコイルの本数だけ配㯰す るとととする。

回路方程式をプラズマあ含めて書く。I を電流の時 間微分，コイルに四加する電压を $V$ とする。

コイルの電殴に注目して,

$[V]=[M][\grave{I}]+\left[m_{K P}\right] \dot{I}_{P}$

ここで, $M:$ インダタタンスマトリックス, $m_{K P}:$ 各コイルとプラズマの相互インダクタ ンス

となる。(11)式を微分して代入すると

$$
(V)=(M)(F)^{-1}\left(\left(\begin{array}{c}
1 \\
1 \\
\vdots \\
1
\end{array}\right) \dot{\Psi}_{B}-\left(F_{P}\right) \dot{I}_{P}\right)+\left(m_{K P}\right) \dot{I}_{P}
$$

となる。鎖交フラックス量は磁束関数の $2 \pi$ 倍であり， 一巻のコイルの相互インダクタンスである。よって相 互インダクタンスマトリックスとの関係は，〔M]= $2 \pi(F)$ 。また。コイル表面上の接点を参照点に選んだ ことにより $\left(m_{K P}\right]=2 \pi\left[F_{P}\right]$ である加ら，(17)式は

$$
(V)=2 \pi\left(\begin{array}{c}
1 \\
1 \\
\vdots \\
1
\end{array}\right) \dot{\Psi}_{B}
$$

となり，各コイルに印加すべき電左は $2 \pi \dot{\Psi}_{B}$ であれ ば良いことになる。すなわち，プラズマ表面の一周電 生を同一にするようにコイル電压を印加すれぱ，プラ
ズマの平衡維持とプラズマ雪流の駆動が同時に行なえ るととを示している。

とのことを $\nabla P=\boldsymbol{j} \times \boldsymbol{B}$ にもとって考察してみる。 プラズマの $P=$ 一定面は $\Psi=$ 一定の面に対応し，プ ラズマの表面 $P=0$ 面は最外郭磁気面であり， $\Psi_{B}=$ 一定加条件である。磁束関数を時間微分すると電王で あるから，プラズマ表面において時々刻々同一電艮に できればプラズマの平衡も維持できるのである。

〈6.2〉プラズマ表面からポロイタルフープが離れ てある場合のコイル制御法 コイルの位置がプラズ マに接するときは，同一電圧でコイルを駆動してやれ ば平衡に必要な電流老流すととができた。では、コイ ルがプラズマから離れた場合すこのようなととはでき ないであるうか。

コイルがすべて一巻のフープとすると，必要電Eは (17)式で求められる。これにコイル抵抗の項を加える べきであるが；值が小さいためとてでは無視して教え る。ここで，各コイルの巻数を $n_{K}$ 巻とすると，必要 なアンペアターン $I_{K}$ 亿対して，コイル電流は $I_{K} \mid n_{K}$ となる。またコイル間の相互インダクタンス $m_{j} k$ は $n_{j} n_{K}$ 倍, プラズマとコイルの相互インダクタンスは $n_{K}$ 倍となる。

(18)式より $K$ 番目のコイルの電E $v_{K}$ は,

$$
\begin{aligned}
v_{K}= & n_{K} n_{1} m_{K 1}\left(\dot{I}_{1} / n_{1}\right)+n_{K} n_{2} m_{K 2}\left(\dot{I}_{2} / n_{2}\right) \ldots \\
& +n_{K} n_{K} m_{K K}\left(\dot{I}_{K} / n_{K}\right) \ldots+n_{K} n_{n}\left(\dot{I}_{n} / n_{n}\right) \\
& +n_{K} m_{K P} \dot{I}_{P} \ldots \ldots \ldots \ldots \ldots \ldots \ldots \ldots \ldots \\
v_{K} / n_{K}= & m_{K 1} \dot{I}_{1}+\cdots+m_{K K} \dot{I}_{K} \\
& +\cdots n_{K n} \dot{I}_{n}+m_{K P} \dot{I}_{P} \ldots \ldots \ldots \ldots
\end{aligned}
$$

となる。（21）式の右辺はコイルを一巻のフープとした 場合の式になる。すなわち，各コイルに必要なアンペ アターン $I_{K}$ ，またプラズマ電流 $I_{F}$ を流すに必要な 電压は，各コイルを一巻と考えた場合の巻数倍の電王 $V_{K}$ が必要であることを示す。各コイル巻数の選択は． ある範囲で自由であるから， $K$ を電源として好ましい 電压を選択してよいととになる。更に進んで，〈6.1〉 節と同じように全コイルを同一電王歌動できれば全コ イルを並列接続することが可能となり，電源の構成す 単純になってくる。すっとす，巻数は整数倍であるの で完全に同一にはならず，過不足分を次章で述べるフ ィードバック電源で䋠うことになる。

\section{7. ハイブリッドコイル制御用電源}

プラズマ電流励起時のプラズマ電流の駆動と平衡維 持は大出力の電源を必要とする。このとき,プラズマ の $R_{P} I_{P}$ が $L_{P} I_{P}$ K比へ無視でき，加つ $L_{i}$ あ一定
昭 $57-9$ 


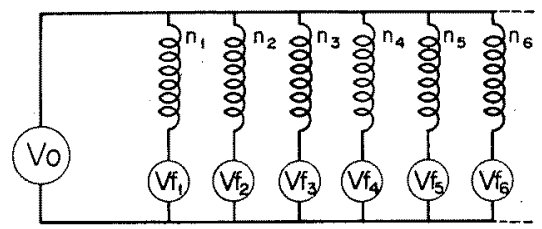

図 5 ハイブリッドポロイダル磁界コイル 電源の基本構成

Fig. 5. Basic diagram of the hybrid poloidal field coil power supply.

であれば，(21)式から決まるコイル巻数の選択により 同一電纴で各コイルが運転できる。とれは各コイルを 並列に接続すれば，一つの電源でプラズマ電流の励起 と平衡維持が可能となるととを示している。これが八 イブリッドポロイダル磁界コイル電源の基本棈成とな る。

ポロイダル磁界コイルによってプラズマのフィード バック制御を行なう際に関係する状態量をコイル電流 に変換するマトリックス（ハイブリッド制御マトリッ クス）を(13)式のように定義することができた。関与 する状態量の中で大きな変化をする $\Psi_{B}, I_{P}$ 以外の状 態量に対するコイル電流の変差はフィードバック電源 の電流制御によって実現するほかはない。このような 考え方でハイブリッドポロイダル磁界コイルを駆動す る電源の基本構成を図 5 に示す。プラズマ電流の励起 ・平衡維持に必要な共通電源 $V_{0}$ とフィードバック制 御用の電源 $V$ ，に分けることができる。共通電源 $V_{0}$ の制御店は，後者に比べてそれほど要求されないか ら, 直流しゃ断器, ダイオード整流器などを使用す る。フィードバック用の電源は正逆の電圧が必要なこ とからサイリスタ電源を使用する。このように，電源 に要求される機能によって使い分けるととにより合理 的な構成となる。

\section{8.むすび}

トカマク形核融合炉において，プラズマ電流の駆動 とプラズマの平衡制貨を総合的に行なうハイブリッド ポロイダル磁界コイル電流の制御法について考察し た。トカマクの平衡ば，プラズマ表面での磁束関数值 せを一定に保つことが条件である。とのことから各コ イルに流すべき電流が決定される。备コイルに流れる 電流は,プラズマ電流励起に関連する部分と平衡維持 に要する成分の合成されたものである。この考えを拡 張して，プラズマ運転に関連するパラメータを流す心゙ きコイル電流に対応させるハイブリッド制御マトリッ クスの考え方導入した。
表 4 ポロイダル磁界コイルシステム

Table 4. System of poloidal field coil.

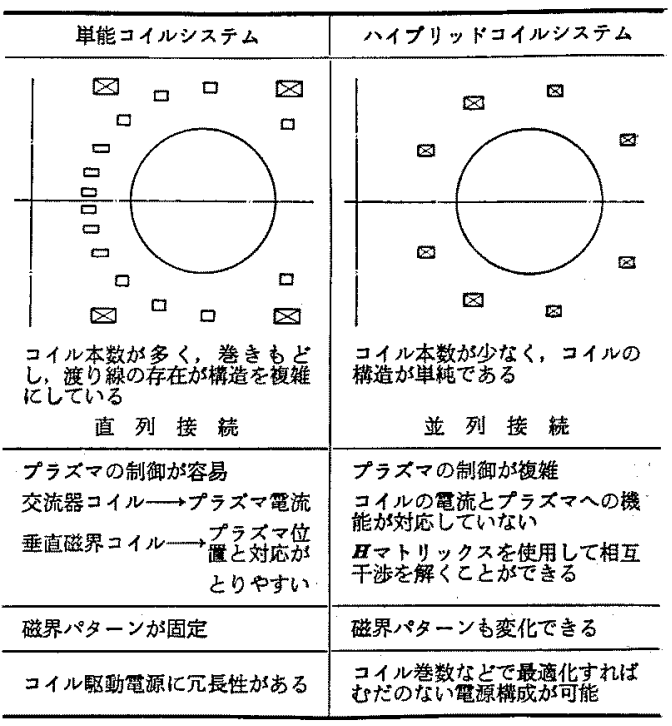

また，このようなハイブリッドポロイダル磁界コイ ルの駆動について，プラズマ電流の立上げ時のように プラズマの運転方案が設定されている場合，各コイル 巻数を最適化することによって合理的な電源を構成す ることができるととを示した。ハイブリッド方式の特 徽を表 4 にまとめて示す。

最後に，本研究を行なうにあたり，終始有益な御助 言をいただいた当可 JT-60 第二開発室田村早苗室長 をはじめ同開発室の諸氏および理論解析研究室の常松 氏に感謝いたします。

(昭和 56 年 12 月 25 日受付, 同 57 年 4 月 30 日再受付)

\section{文献}

(1) 撚田·谷・田村: 電学論 A, 99, 49 (昭 54-2)

(2) 㐊川: 雷学誌, 96,879 (昭 51-10)

(3) 小林・田村・谷: JAERI.M, No. 5898 (昭 49)

(4) 相川!二宮・鼠有・鈴木: 同上, No. 6552 (昭 51)

(5) フルツィモர゙ィチ:関じたプラズマ欺位の平衡」,プラズマ 閉込めとトカマク，第2 章 (四 47) 東京図畫

（6）吉川·饭吉; 「閉じ迅的磁埸」，核融合入門，第 2 章 (昭 47) 共立出版

(7) Y. Suzuki: Nuclear Fusion, 14, 345 (1974)

(8) T. Takeda \& T. Tsunematsu: JAERI-M, No. 8042(1979)

(9) H. Ninomiya, et al.: Optimization of Currents in FieldShaping Coils of a Non-Circular Tokamak", Proc, 8 th Symp. on Engineenng Problems on Fusion Research, 1, 75 (1979)

(10) L.E. Zakharov: Nuclear Fusion, 13. 595 (1973)

(11) V. D. Shafranov \& L. E. Zakharov: ibid., 12, 599(1972)

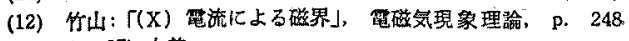
(昭 37) 丸暨 